\title{
Enhanced or not? The role of defence Counsel in China
}

\author{
Jiang $\mathrm{Na}^{* 1}$ and Kang Linlin ${ }^{2}$ \\ ${ }^{1}$ Law Professor, Beijing Normal University in China, China \\ ${ }^{2}$ LLM candidate, Law School of Beijing Normal University, China
}

Submission: May 18, 2019; Published: May 30, 2019

*Corresponding author: Jiang Na, Law Professor, Beijing Normal University in China, Deputy General-Secretary of the International Association of Penal Law (AIDP) China Branch, China

\section{Opinion}

As the white paper demonstrates, China has enhanced the role of defence counsel in the criminal process. For example, when the SPC "reviews capital cases, it focuses on interrogating the defendant in accordance with the law and listening to opinions of the defence counsel [1]." It is true that paying greater attention to the advice of defence counsel could help the SPC fully examine facts and evidence in order to impartially conclude cases. But is listening to them not a part of a fair trial in all criminal cases? In fact, all courts need do so to keep the prosecution and defence in balance and ensure justice by law. In official opinions, "China is striving to drive reform of the judiciary to a deeper level promote judicial transparency, establish a national judicial assistance system, and ensure the right of lawyers to practice their profession" [2]. Clearly, conducting final reviews and listening to defence counsel in limited circumstances are insufficient, and China remains far from such goals.

In order to ensure lawyers' right to practice, the white paper states that, in 2015, the SPC, the SPP, the MPS, the Ministry of State Security (MSS), and the MOJ "jointly issued the Regulations on Protecting Lawyers' Right of Practice in Accordance with the Law, which further implements relevant legal provisions, makes clear various measures to protect lawyers' right of practice, makes it more convenient for lawyers to participate in litigation, and improves the remedy and accountability mechanisms for ensuring lawyers' right to practice". As officially stated, "judicial organs have protected lawyers' rights to know, their rights of application and appeal, and the rights to meet their clients, to read case files, to collect evidence and ask questions, to crossexamine, and to debate in court" so as to ensure lawyers are not deterred from practicing law as defence counsel or from adequately representing their clients. The new provisions relating to lawyers; rights also appear in the $2012 \mathrm{CPL}$, but neither the new regulations nor the law can overcome the actual obstacles arising from power abuse by the police, prosecutors or courts.

For instance, as the white paper emphasizes, the police "have provided lawyers with meeting rooms, and opened online platform for lawyers to make appointments to visit their clients and made known to the public such appointment phone numbers, providing convenience to meetings between lawyers and their clients and ensuring their conversations are not monitored." More convenience is helpful, but police obstruction of lawyers' meetings with their clients still persists, particularly in serious cases. The white paper officially stresses, that PR curatorial organs "have effectively fulfilled their role in the supervision over the obstruction of lawyers' rights" [3] in many cases involving infringement of their procedural rights. Even so, Chinese lawyers still face the high risk of obstruction or penalties when defending the accused in practice. Also, the white paper states that in 2015 "the SPC launched a service platform for lawyers" to offer convenient legal services, such as "online case registration, online access to case files, case information inquiry, electronic service of legal documents, and judges' contact details [4]." It further states that in 2016, "the SPC issued the Regulations on Effectively Protecting Lawyers' Procedural Rights in Accordance with the Law", which "clarifies the protection of lawyers' procedural rights and personal safety by courts, and stipulates that courts should provide lounges with desks, chairs, drinking water and other necessities for lawyers participating in court trials." Even if the courts provision of rooms for lawyers might protect their dignity, such convenience or facilities cannot encourage them to investigate or collect evidence, or well-protect themselves or their clients from being wrongly convicted in defending justice.

Concerning legal assistance, China has taken some measures to improve the system of legal aid, as the white paper affirms. But there is still a long way to go before a complete or effective 
legal aid system is established in practice. In a recent survey covering most provinces of china, it was found that the accused were assisted by defence counsel in only $22 \%$ of cases [5]. For example, in Henan province, the defence rate of all criminal cases is close to the above percentage, of which the accused in $30 \%$ or so depend on national legal aid in order to get access to counsel's help and the other can afford their fee. Without lawyers' help, it is very hard for the innocent to defend or protect themselves from wrongful convictions resulting from tortured confession [6]. Also, according to the survey, the accused with legal aid accounted for merely $7.33 \%$ of all surveyed criminal cases. After the 2012 reform in implementing the 2012 CPL, national funds are allocated to the Legal Aid Center which pays fees to lawyers so that they can get more legal aid fees than ever before, but the financial support of legal aid is still far from meeting lawyers' actual needs in handling such cases. The interviewed judges [7] often agree that the legal aid fee of 500 or $700 \mathrm{RMB}$ in each criminal case cannot make up for basic costs, like the traffic fee that lawyers have to pay for meeting suspects or the accused several times in order to prepare for defence at trial, not to mention a fee to cover the lawyer's labor fee for hours work. It is not rare but happens in all China.

For example, in the capital city of Henan province, the legal aid fee for each criminal case is generally 1,000 RMB. After the administration bureau takes off $200 \mathrm{RMB}$ and the law firm deducts some alongside the newly established legal aid foundation under the Legal Aid Center, defence lawyers only have the remainder, less than $800 \mathrm{RMB}$, less than $1 / 12$ of 10,000 $\mathrm{RMB}$, the minimum fee charged for each criminal case in many law firms. Most of the interviewed lawyers would rather wait for rich clients to hire them than volunteer to provide legal aid. It is no wonder that Chinese lawyers often take it as hard work, so that trials with their inadequate defence cannot make any difference to justice and even becomes a symbolic show, as usual. More importantly than inadequate legal aid, defence lawyers face the risk of prosecution in the criminal process, further leading to the shortage of criminal defence. This professional risk mainly results from law enforcement officers' threats of retaliation against or persecution of lawyers themselves. For example, those who fear that defence lawyers might defeat the prosecution's evidence may abuse Article 306 of the 1997 CL to charge them with falsifying evidence in order to prevent their effective defence.

It is Article 306 that criminalizes the defender who, when acting in a criminal case, "destroys or forges evidence, helps any of the parties destroy or forge evidence, or coerces the witness or entices him into changing his testimony in defiance of the facts or give false testimony". Similarly, the all-inclusive legislative approach, i.e., "other conduct that disrupts court order" appears in many provisions, like Article 309 of the $1997 \mathrm{CL}$, those of Law on Lawyers or the 2012 CPL. The overbroad scope of the above conduct is so "open to abusive interpretation and application" as to undermine the principle of legal certainty, which "may deter lawyers from raising reports of torture in their clients' defence for fear of reprisals, weakening the safeguards of the rule of law that are necessary for the effective protection against torture" [8]. The articles are used as a tool for the retaliatory prosecution of lawyers, who face fixed-term imprisonment, detention, surveillance or fine if convicted.

\section{Summary}

As demonstrated in the white paper, Chinese official opinions are full of achievements and generalizations of new reforms, but they are written in political language and omit practical problems. Given the current justice situation, such statements, like that the implementation on human rights provisions, i.e., guarantees from improvements the evidence or defence system, are just presenting political desires or legal intentions. Also, this positive perspective or partial opinion is common in official expressions in domestic media, indicating its insufficient courage to comment on flaws in the justice system to the public and lacking ideas on how to substantively mend them.

\section{References}

1. The State Council Information Office of the People's Republic of China (2016) White Paper: New Progress in the Judicial Protection of Human Rights in China, SCIO.

2. Ibid.

3. Ibid.

4. Ibid.

5. See MA Jinghua (2011) Criminal defense rates and their formation mechanism - with the first instance of criminal cases at the core, 6 Journal of Sichuan University, China.

6. See Reiman J, Leighton P (2009) The Rich Get Richer and the Poor Get Prison: Ideology, Class, and Criminal Justice, ( $9^{\text {th }}$ edn), Pearson, New York, USA, also see Bai J The impact of latent rules on conviction process (Lun sifa qianjian dui dingzui guocheng de yingxiang), 2013 Soc Sci China 1: 167.

7. The author has carried out in-depth interviews with 33 judges and lawyers in H province, S city and G province of China since 2015.

8. Committee Against Torture, Concluding observations CAT/C/CHN/ CO/5, paras. $13,19,23$ and 31 . 
(c) (i)

This work is licensed under Creative Commons Attribution 4.0 License DOI: 10.19080/GJAA.2019.09.555768
Your next submission with Juniper Publishers will reach you the below assets

- Quality Editorial service

- Swift Peer Review

- Reprints availability

- E-prints Service

- Manuscript Podcast for convenient understanding

- Global attainment for your research

- Manuscript accessibility in different formats ( Pdf, E-pub, Full Text, Audio)

- Unceasing customer service

Track the below URL for one-step submission https://juniperpublishers.com/online-submission.php 